\title{
Potensi Jamur Kuping Hitam (auricularia polytricha) Sebagai Terapi Alternatif Diabetes Melitus
}

\author{
Dhea Oksalia Edi ${ }^{*}$ \\ ${ }^{1}$ Fakultas Kedokteran, Universitas Lampung \\ Email : dheaoksalia@gmail.com
}

\begin{abstract}
ABSTRAK
Dewasa ini penderita penyakit gangguan metabolik terus mengalami peningkatan jumlah penderita. Salah satu dari penyakit gangguan metabolik yaitu Diabetes melitus atau masyarakat awam mengenalnya dengan penyakit kencing manis. Prevalensi diabetes melitus di Indonesia diperkirakan akan mencapai 21,3 juta orang pada tahun 2030. Diabetes melitus ditandai oleh meningkatnya kadar glukosa dalam darah yang disebabkan karena kelainan sekresi insulin, penurunan kerja insulin ataupun keduanya. Diabetes melitus berkaitan erat dengan komplikasi berupa makroangiopati ataupun mikroangiopati. Banyak negara mengembangkan senyawa herbal yang memiliki khasiat menurunkan kadar glukosa dalam darah seperti jamur kuping hitam (Auriculria polytricha). Jamur kuping hitam mengandung flavonoid dan polisakarida berupa serat $(43,2 \%)$ yang berperan penting dalam menurunkan kadar glukosa darah. Mekanisme kerja flavonoid dalam menurunkan kadar glukosa darah yaitu menurunkan penyerapan glukosa dengan menghambat GLUT 2 mukosa, meningkatkan pemakaian glukosa di jaringan perifer dan menurunkan stress oksidatif. Sedangkan polisakarida dapat mengendalikan penyerapan glukosa pada pencernaan sehingga mampu menurunkan kadar glukosa darah.
\end{abstract}

Kata kunci : Auricularia polytricha, diabetes melitus, flavonoid, glukosa darah, polisakarida

\begin{abstract}
ABSTRAK
Nowadays patients with metabolic disorders are continously increase recently. One of those metabolic disorder is Diabetes mellitus or people know as "kencing manis" disease. The prevalence of diabetes mellitus in Indonesia is estimated to be as many as 21,3 million people in 2030. Diabetes mellitus is characterized by the increase of glucose levels in the blood caused by the abnormalities of insulin secretion, the decrease of insulin function or both. Diabetes mellitus is closely related to complications such as macroangiopathy and microangiopathy. There are many countries elaborate herbal coumpounds that have efficacy for decreasing blood glucose levels such as wood ear mushroom (Auricularia polytricha). Wood ear mushroom contains is flavonoid and polyssacharides in form of fiber $(43,2 \%)$ which havean important role in decreasing blood glucose levels. The mechanisms how flavonoids decrease blood glucose levels is by decrease glucose absorption by inhibit the intestinal mucosa GLUT 2, decrease stimulation of peripheral glucose utilisation and decrease oxidative stress. Polysaccharides help to control the glucose absorptionin the gastrointestinal to maintain the blood glucose levels.
\end{abstract}

Keywords : Auricularia polytricha, blood glucose, diabetes mellitus, flavonoid, polysaccharides 


\section{Pendahuluan}

Dewasa ini jumlah penderita penyakit metabolik terus mengalami peningkatan. Salah satunya adalah Diabetes melitus atau masyarakat awam mengenalnya dengan penyakit kencing manis. Prevalensi diabetes melitus di Indonesia bervariasi. Pada tahun 2013 melalui Riset Kesehatan Dasar dilakukan pemeriksaan glukosa darah pada penduduk Indonesia usia 15 tahun ke atas, dan didapatkan proporsi yaitu penderita diabetes melitus (DM) yakni 6,9\%, toleransi glukosa terganggu (TGT) 29,9\% dan glukosa darah puasa terganggu (GDP terganggu) sebesar 36,6\% (Kementerian Kesehatan RI, 2014). Di Indonesia diperkirakan prevalensi penderita diabetes melitus akan mencapai 21,3 juta orang pada tahun 2030 (Kementerian Kesehatan RI, 2019). Sedangkan menurut International Diabetes Federation (IDF) pada tahun 2013 terdapat 382 juta orang penderita diabetes di dunia dan diperkirakan pada tahun 2035 akan meningkat menjadi 592 juta orang penderita.

Diabetes melitus (DM) merupakan suatu kelompok penyakit metabolik yang ditandai dengan meningkatnya kadar glukosa dalam darah akibat kekurangan sekresi insulin, penurunan efektifitas kerja insulin ataupun akibat keduanya (Ndraha, 2014). Diabetes melitus merupakan salah satu penyakit yang erat kaitannya dengan komplikasi berupa makroangiopati seperti penyakit jantung koroner, penyakit pada pembuluh darah seperti stroke dan penyakit pembuluh darah perifer. Dapat juga menimbulkan komplikasi berupa mikroangiopati seperti pada glomerulus ginjal (nefropati diabetik) dan retinopati diabetik. Angka kesakitan Diabetes Melitus dapat meningkat pada penderita usia lanjut (Lansia). Menurut penelitian sebelumnya yang dilakukan dengan metode wawancara, didapatkan hasil bahwa para lansia rata-rata mengalami penyakit stroke dan tidak melakukan pemeriksaan rutin di Posyandu yang telah disediakan (Sulaiman dan Anggraini, 2017). Prinsip dasar pengobatan pada penderita diabetes melitus adalah mengontrol kondisi diabetesnya secara rutin dan mencegah terjadinya komplikasi (Depkes RI, 2005).

Saat ini, banyak negara yang telah mulai mengembangkan senyawa herbal guna pengobatan. Tumbuhan obat menjadi salah satu pilihan untuk dijadikan obat anti diabetes melitus karena tumbuhan tersebut memiliki kandungan yang berkhasiat sebagai anti diabetes melitus dengan efek samping yang minimum dan biaya yang terjangkau.

Salah satu tanaman yang sudah dilakukan penelitian sebelumnya memiliki efek menurunkan kadar glukosa dalam darah yaitu jamur kuping hitam (Auricularia polytricha). Hal ini berkaitan dengan kandungan flavonoid dan polisakarida yang terkandung di dalamnya. Menurut penelitian Ni Jung Wu (2014) didapatkan bahwa ekstrak air panas dari jamur kuping hitam (Auricularia polytricha) secara in vitro memiliki kandungan senyawa flavonoid dan polisakarida yang memiliki efek menurunkan kadar glukosa (Ni Jung Wu et al., 2014).

\section{Isi}

Diabetes melitus merupakan penyakit yang ditandai dengan kadar glukosa dalam darah yang melebihi normal (hiperglikemi) sebagai akibat dari kekurangan sekresi insulin relatif maupun absolut, penurunan efektifitas kerja insulin ataupun keduanya (Purnamasari, 2009).

Klasifikasi diabetes melitus berdasarkan etiologinya menurut American Diabetes association 2018 dibagi menjadi beberapa kategori yaitu (Ndraha, 2014; American Diabetes Association, 2018) :

a) Diabetes Melitus Tipe 1 atau Insulin Dependent Diabetes Mellitus/IDDM.

DM Tipe 1 terjadi karena adanya destruksi sel beta pankreas yang menyebabkan terjadinya defisiensi insulin absolut, dapat terjadi melalui proses autoimun ataupun idiopatik.

b) Diabetes melitus Tipe 2 atau Insulin Independent Diabetes Mellitus/NIDDM.

DM Tipe 2 terjadi karena adanya resistensi insulin atau ketidakmampuan reseptor insulin untuk merangsang pengambilan glukosa oleh jaringan perifer dan untuk menghambat produksi glukosa oleh hati. Oleh karenanya terjadi resistensi (resptor insulin sudah tidak 
aktif karena dianggap kadarnya masih tinggi dalam darah). Onset DM tipe 2 ini terjadi perlahan dengan gejala asimtomatik. DM tipe ini sering terdiagnosis setelah terjadi komplikasi.

c) Diabetes Gestasional

DM Gestasional biasa nya didapati pertama kali pada kehamilan trisemester kedua atau ketiga. Umumnya bersifat sementara, tetapi riwayat kehamilan dengan diabetes gestasional merupakan faktor resiko untuk menderita DM Tipe 2 yang menetap dalam jangka waktu 510 tahun setelah melahirkan.

d) Diabetes Melitus Tipe Lain

DM tipe lain ini terjadi karena etiologi yang beragam, seperti karena adanya defek genetik fungsi pada sel beta pankreas, adanya pengaruh dari obat/ zat kimia seperti glukokortikoid, asam nikotinat, pentamidin, tiazid, adanya defek genetik kerja insulin, endokrinopati, infeksi virus, penyakit autoimun, ataupun karena adanya penyakit eksorin pankreas seperti pankreatitis, trauma, neoplasma, dan cistic fibrosis.

Diagnosis diabetes melitus dapat ditegakkan bila (Bahagia, 2018):

a) Setelah dilakukan pemeriksaan didapatkan nilai glukosa darah sewaktu (GDS) $>200 \mathrm{mg} / \mathrm{dl}$ ditambah dengan 4 gejala khas DM positif, yaitu sering berkemih, sering merasa lapar, sering merasa haus, dan mengalami penurunan berat badan.

b) Setelah dilakukan pemeriksaan didapatkan nilai glukosa darah puasa (GDP) $>126 \mathrm{mg} / \mathrm{dl}$ ditambah dengan 4 gejala khas DM positif.

c) Pemeriksaan HbA1c $\geq 6,5 \%$ dengan menggunakan metode yang terstandarisasi oleh National Glycohaemoglobin Standardization Program (NGSP).

Langkah-langkah mendiagnosis diabetes melitus akan dijelaskan pada gambar 1.

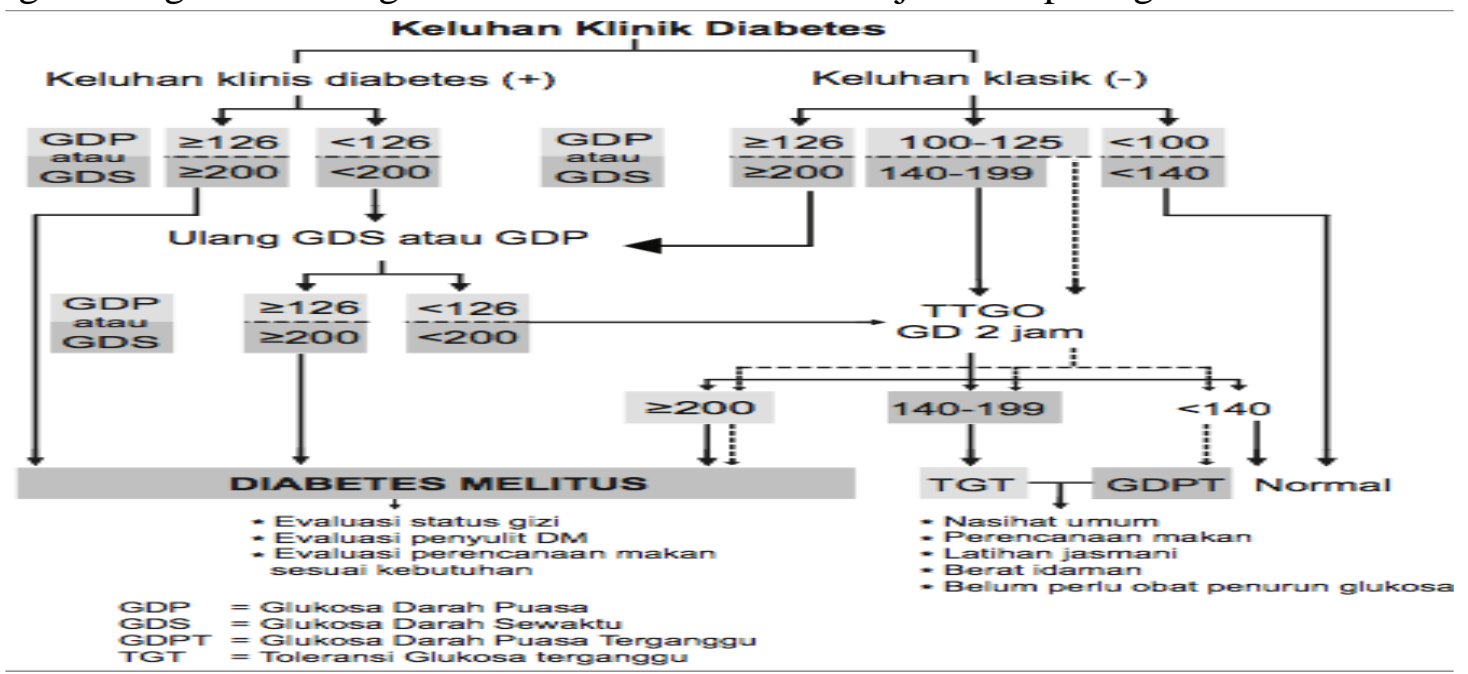

\section{Gambar 1. Langkah-langkah diagnosis DM, TTGO dan TGT (Purnamasari, 2009)}

Jamur kuping hitam (Auricularia polytricha) merupakan salah satu jenis jamur yang dapat dimanfaatkan sebagi bahan pangan, dikenal sebagi jamur jelly hitam yang mengandung serat yang tinggi. Jamur kuping hitam banyak dibudidayakan di daerah tropis salah satunya Indonesia (Wardani, 2010).

Berdasarkan taksonomi jamur kuping hitam termasuk dalam divisi amastigomycota, subdivisi basidiomycotae, kelas basidiomycetes, ordo auriculariales, familia auriculariae dan genus auricularia (Angriawan, 2006). Jamur kuping memiliki permukaan sedikit mengkilat, berurat, dan bagian bawahnya halus seperti beludru. Jamur ini berbentuk seperti cendawan pipih dengan tepi melengkung ke atas. Tubuh buahnya berlekuk-lekuk dengan lebar $3-8 \mathrm{~cm}$, tebalnya sekitar 0,1-0,2cm dan berwarna coklat tua kehitaman. Sel jamur tidak mengandung 
klorofil sehingga tidak dapat berfotosintesis seperti tumbuhan tingkat tinggi. Jamur ini memperoleh makanan secara heterotrof dengan mengambil makanan dari bahan organik yang ada di sekitar tempat tumbuh. Jamur kuping memiliki tangkai buah yang pendek dan menempel pada substrat. Bentuk Auricularia polytricha akan dijelaskan pada gambar 2.

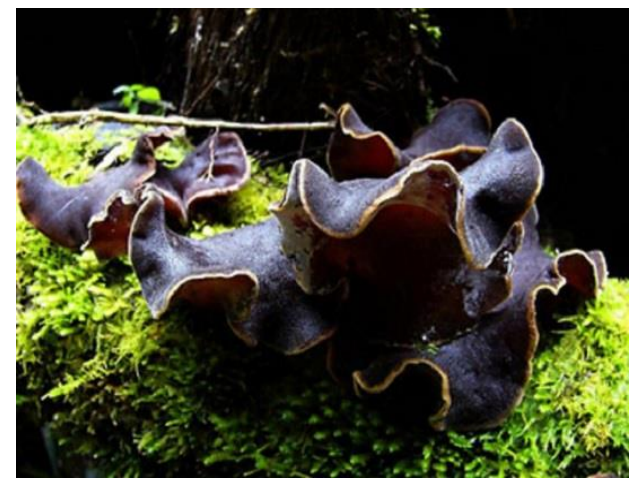

Gambar 2. Auricularia polytricha.

Berdasarkan penelitian yang dilakukan oleh Liana et al (2015) simplisia dan ekstrak etanol jamur kuping mengandung senyawa aktif seperti flavonoid. Hasil skrining fitomikia jamur kuping hitam (Auricularia polytricha) akan dijelaskan pada tabel 1.

Tabel 1. Hasil Skrining Fitokimia Simplisia dan Ekstrak Jamur Kuping Hitam (Liana et al., 2015).

\begin{tabular}{|c|c|c|}
\hline \multirow[t]{2}{*}{ Golongan senyawa } & \multicolumn{2}{|c|}{ Sampel } \\
\hline & Simplisia & Ekstrak \\
\hline Alkaloid & + & + \\
\hline Polifenolat & - & - \\
\hline Flavonoid & + & + \\
\hline Saponin & - & - \\
\hline Kuinon & - & - \\
\hline Tanin & - & - \\
\hline Monoterpen dan Seskuiterpen & + & + \\
\hline Triterpenoid dan Steroid & - & - \\
\hline
\end{tabular}

$$
\begin{array}{ll}
\hline \text { Keterangan: } & (+)=\text { Terdeteksi } \\
& (-)=\text { Tidak terdeteksi }
\end{array}
$$

Flavonoid merupakan salah satu kelompok senyawa metabolit sekunder yang termasuk dalam golongan senyawa phenolik (Ajie, 2015). Flavonoid diketahui memiliki aktivitas antioksidan yang berkaitan dengan kemampuannya menurunkan kadar glukosa darah (Sasmita et al., 2017). Flavonoid yang terkandung di dalam jamur kuping hitam diduga bersifat protektif terhadap kerusakan sel beta pankreas sebagai penghasil insulin serta dapat meningkatkan sensitivitas insulin (Sasmita et al., 2017). Mekanisme flavonoid terutama quercetin dalam menurunkan kadar glukosa dalam darah adalah menurunkan penyerapan glukosa dengan menghambat GLUT 2 mukosa usus. GLUT 2 merupakan transporter mayor glukosa di usus pada kondisi normal (Song et al., 2002). Selain itu flavonoid juga meningkatkan pemanfaatan glukosa di jaringan perifer dan otot skeletal dengan cara menekan jalur glikogenolisis dan glukoneogenesis (Sasmita, 2017).

Mekanisme lain adalah kemampuan flavonoid sebagai antioksidan yang dapat menurunkan Reactive Oxygen Species (ROS) (Annisa et al., 2014). Menurut Widowati (2008) 
sumber stress oksidasi diabetes terjadi karena perpindahan keseimbangan reaksi redoks yang akan meningkatkan pembentukan ROS akibat perpindahan keseimbangan reaksi redoks akibat perubahan metabolisme lipid dan karbohidrat. Antioksidan dalam flavonoid dapat menyumbangkan atom hidrogen dan akan teroksidasi serta berikatan dengan radikal bebas sehingga diharapkan radikal bebas menjadi senyawa yang lebih stabil. Flavonoid juga dapat membantu merangsang sekresi insulin dan meregenerasi sel beta pankreas (Sasmita, 2017).

Berdasarkan penelitian Fitrianingsih et al (2015) menyebutkan bahwa ekstrak jamur kuping hitam (Auricularia polytricha) memiliki efek menurunkan kadar glukosa darah pada ekstrak dengan dosis $60 \mathrm{mg} / 20 \mathrm{~g}$ BB mencit ditinjau dari kadar glukosa darah rata-rata mencit di menit ke-120 yang memberikan perbedaan bermakna terhadap kontrol dengan nilai persentase penurunan kadar glukosa darah sebesar 58,2\%. Selain itu, didukung oleh penelitian sebelumnya berdasarkan penelitian Ni-Jung Wu (2014) ekstrak air panas dari jamur kuping hitam (Auricularia polytricha) secara in vitro memiliki kandungan polisakarida berupa serat $(43,2 \%)$ menunjukkan adanya respon dalam mencegah peningkatan kadar glukosa postprandial dengan cara mengendalikan penyerapan glukosa yakni dengan menekan aktivitas enzim $\alpha$ amilase.

\section{RINGKASAN}

Penderita penyakit metabolik semakin hari semakin meningkat. Salah satunya adalah penyakit diabetes melitus. Penyakit ini merupakan penyakit kronik dan memiliki kaitan erat dengan komplikasi berupa makroangiopati ataupun mikroangiopati. Prinsip tujuan terapi diabetes melitus adalah mengontrol kondisi glukosa darah pasien dan mencegah terjadinya komplikasi.

Jamur kuping hitam (Auricularia polytricha) merupakan salah satu jenis jamur yang sering dibudidayakan dan dijadikan sebagai bahan pangan. Jamur kuping hitam mengandung senyawa aktif utama yaitu flavonoid yang berperan sebagai antioksidan juga sebagai antidiabetes. Mekanisme flavonoid dalam menurunkan kadar glukosa darah adalah dengan menurunkan penyerapan glukosa dengan menghambat GLUT 2 mukosa intestinal, selain itu flavonoid mampu meningkatkan pemanfaatan glukosa pada jaringan perifer dan berperan sebagai antioksidan sehingga menurunkan Reactive Oxygen Species (ROS). Selain itu kandungan polisakarida pada jamur tiram dapat menekan aktivitas enzim $\alpha$ amilase sehingga mencegah peningkatan kadar glukosa dalam darah.

\section{Kesimpulan}

Jamur kuping hitam mengandung senyawa flavonoid dan polisakarida. Flavonoid merupakan senyawa antioksidan yang memiliki efek hipoglikemi pada penderita diabetes melitus. Sedangkan polisakarida berupa serat yang tinggi dapat mengendalikan penyerapan glukosa darah sehingga memiliki potensi sebagai terapi alternatif untuk menurunkan glukosa darah. 


\section{Referensi}

Ajie, Rizky Bayu. 2015 White dragon fruit (Hylocereus undatus) potential as diabetes mellitus treatment. J Majority. 4(1): 69.

American Diabetes Association. 2018. Standards of medical care in diabetes USA: ADA. 2018; 41(Suppl 1):S1-S159.

Angriawan, Teddy. 2006. Budidaya jamur kuping (Auricularia polytricha) [Tugas akhir]. Jawa Tengah: Universitas Sebelas Maret.

Annisa A, Viryawan C, Santoso F. 2014. Hipoksia berpeluang mencegah kerusakan sel $\beta$ pankreas pada pasien diabetes melitus tipe 2: Tinjauan biologi molekuler. CDK. 41(3): 198-9.

Bahagia W, Kurniawaty E, dan Mustafa S. 2018. Potensi Ekstrak Buah Pare (Momordhica charantia) sebagai penurun kadar glukosa darah: manfaat di balik rasa pahit. Majority. 7(2): 177-181.

Depkes RI. 2005. Pharmaceutical care untuk penyakit diabetes melitus. Jakarta: Direktorat Bina Farmasi Komunitas dan Klinik Direktorat Jenderal Bina Kefarmasian dan Alat Kesehatan Departemen Kesehatan RI.

Fitrianingsih SP, Mulqie L, Lukmayani Y, Liana M. 2015. Efek pemberian ekstrak jamur kuping hitam terhadap penurunan kadar glukosa darah secara in vivo. Prosiding SnaPP 2015 Kesehatan. 1(1):371-376.

Kemenkes RI. 2014. Situasi dan analisis diabetes. Jakarta: Pusat Data dan Informasi Kementrian Kesehatan RI.

Kementrian Kesehatan RI. Tahun 2030 prevalensi diabetes melitus di Indonesia mencapai 21,3 juta orang.2009. [disitasi tanggal 8 September 2019]. Tersedia dari: http://www.depkes.go.id/article/view/414/tahun-2030-prevalensi-diabetes-melitus-diindonesia-mencapai-213-juta-orang.html

Liana M, Fitrianingsih SP, Mulqie L. 2015. Karakteristik simplisia dan ekstrak etanol jamur kuping hitam (Auricularia polytricha). Prosiding Penelitian SPeSIA Unisba. 267-273.

Ndraha S. 2014. Diabetes melitus tipe 2 dan tatalaksana terkini. Medicinus. 27(2):9-16.

Ni-Jung Wu, Fu-Jing Chiou,Yih-Ming Weng, Zer-Ran Yu, Be-Jen Wang. 2014. In vitro hypoglicemic effect of hot water extract from Auricularia polytricha (Wood Ear Mushroom). Taiwan : International Journal Food Science and Nutrition. Vol. 65 (4).

Purnamasari, D. 2009. Diagnosis dan klasifikasi diabetes melitus. Dalam: Sudoyo AW, Setyohadi B, Alwi I, Marcellus SK dan Setiadi S. Buku ajar ilmu penyakit dalam. Jld 3 Ed. 5. Jakarta: Interna Pub.

Sasmita FW, Susetyarini E, Husamah, Pantiawati Y. 2017. Efek ekstrak daun kembang bulang (Tithonia diversifolia) terhadap kadar glukosa darah tikus wistar (Rattus novergicus) yang diiinduksi aloxan. Biosfera. 34(1):22-31.

Song J, Kwon O, Chen S, Daruwala R, Eck P, Park JB, Levine M. 2002. Flavonoid inhibition of SVCT1 and GLUT2, intestinal trasporters for vitamin C and glucose. J. Biol. Chem. [disitasi 9 November 2019]. Tersedia dari http://www.jbc.org/.

Sulaiman, Anggriani. 2017. Sosialisasi pencegahan kasus stroke pada lanjut usia di Desa Hamparan Perak Kecamatan. Jurnal Pengabdian Kepada Masyarakat. 1(2):70-74.

Wardani, Isnaen. 2010. Budidaya jamur konsumsi. Yogyakarta: Lily publishing.

Widowati, W. 2008. Potensi anktioksidan sebagai antidiabetes. Jurnal Kedokteran Marantana. $7(2)$. 